\title{
Primary hepatocellular carcinoma presenting as fulminant hepatic failure in a young woman
}

\author{
L.J. Levy, L. M. Swinburne, R.P. Boulton and M.S. Losowsky \\ Department of Medicine, St. James's University Hospital, Leeds LS9 7TF, UK.
}

\begin{abstract}
Summary: A 29 year old Caucasian female, with no history of chronic liver disease, presented with fulminant hepatic failure, the cause of which was not established until post-mortem when it was found that she had a rare form of hepatocellular carcinoma. To our knowledge, this is the only detailed report of hepatocellular carcinoma presenting in this manner.
\end{abstract}

\section{Introduction}

Fulminant hepatic failure is most commonly seen following viral hepatitis, paracetamol overdose and halothane anaesthesia. Less common causes include fatty liver of pregnancy and hypersensitivity to drugs (Saunders et al., 1979).

Although there are reports of metastatic liver disease presenting as fulminant hepatic failure (Mallory et al., 1946; Krauss et al., 1979; Hess \& Joyce, 1981; Harrison et al., 1981; Braude et al., 1982) there is only one report of a primary hepatic malignancy presenting in this way (Stein et al., 1977). This was a malignant haemangioendothelioma.

We report a patient who presented with fulminant hepatic failure as a result of hepatocellular carcinoma.

\section{Case report}

A 29 year old Caucasian female presented with a 6month history of anorexia, lethargy and malaise, and a 3-month history of fluctuant jaundice associated with dark urine and pale stools. Her family had noted in the few days before admission that she had been behaving out of character. Although she had previously been on an oral contraceptive, she had not taken it for 3 years.

On examination she was jaundiced but there were no signs of chronic liver disease.

Laboratory results showed a normal full blood count and serum electrolyte and creatinine levels.

The results of initial liver function tests were (normal ranges are given in brackets): bilirubin $293 \mathrm{mmol} / 1(3-15)$, aminoalanine transferase $553 \mathrm{IU} /$ 1 (0-35), alkaline phosphatase $25.8 \mathrm{KAU} / \mathrm{dl}(3-13)$, total protein $53 \mathrm{~g} / 1(61-77)$, albumin $34 \mathrm{~g} / 1$ (37-49).

Correspondence: L.J. Levy, B.Sc., M.B., Ch.B.

Accepted: 21 July 1986
The prothrombin time was 49 seconds (control 12 seconds). Virology studies and tests for hepatitis A, B, toxoplasma, brucella and leptospirosis were negative. Serum $\alpha_{1}$-antitrypsin, caeruloplasmin and copper were within normal limits. The auto-antibody screen was negative. No $\alpha$-fetoprotein was detected. Serum ferritin was elevated at $770 \mu \mathrm{g} / 1$. A biopsy was not performed because of the coagulation disturbance. Ultrasound examination of the liver was attempted, but no suitable views were obtained.

Two days after admission, the patient became drowsy and disorientated, and developed a flapping tremor. An electroencephalogram showed typical biphasic and triphasic waves of hepatic pre-coma. Despite full supportive therapy, her hepatic function continued to deteriorate with rapid worsening of her conscious level. She died 10 days after admission in grade IV hepatic coma with hepato-renal failure.

At post-mortem the liver was shrunken with a yellowish-brown capsular surface on which there were bright yellow nodules of irregular shape. Confluent nodules formed large geographical areas on the surface of both right and left lobes. The nodules were more conspicuous and numerous on the cut surfaces. In addition, there were two or three round white nodules up to $0.5 \mathrm{~cm}$ in diameter and a nodule of friable pink tissue $0.5 \mathrm{~cm}$ alongside the junction of the common bile duct and the ampulla. The lumen of the duct was unobstructed. The spleen was not enlarged and was of normal consistency. There was slight cerebral oedema. No metastases were seen.

Histology demonstrated a largely necrotic liver. There were extensive areas of dead tissue in which small bile ducts were preserved and were of normal structure. There was no evidence of pre-existing hepatic disease or fibrosis, but minor changes would have been obscured by the massive infarction. 
In some areas, at the edges of necrotic tissue, there was a patchy, sparse infiltrate of mixed inflammatory cells.

The tumour appeared to be composed of two major elements. The predominant element in samples from many sites was a diffuse hepatocellular carcinoma, composed of cords and trabeculae of tubulo-acinar structure. The cells were triangular or polygonal, with relatively abundant eosinophil cytoplasm and conspicuous bile secretion (Figure 1). They resembled normal hepatocytes but, in a few areas, there were cell nests with dysplastic and enlarged nuclei. Giant cells were not seen. There was no bile duct proliferation or desmoplasia in relation to the tumour. Virtually no normal viable hepatic tissue could be found nor was there direct evidence of vascular invasion by the tumour.

The minor element consisted of well differentiated mucin-secreting white nodules and also the small nodule outside the common bile duct. In the latter there was a clear-cut transition in structure from one element to the other (Figure 2). The conclusion was that this was a rare variant of primary liver-cell carcinoma.

\section{Discussion}

This hepatocellular carcinoma is unusual both in the manner in which it presented and the patient in whom it occurred.

Hepatocellular carcinoma in adults is largely a disease of 50-70 year olds, with a strong male predominance. However, there is a variant with distinctive histological features that occurs mainly in children and young adults. Known as fibrolamellar carcinoma, this tumour is rich in fibrous tissue, is more common in females and is associated with a better prognosis (Farhi et al., 1983). Our patient showed none of the clinical or pathological features of this. The tumour observed in our patient consisted of combined liver cell and bile duct elements with a transition between them. This is a very rare feature of hepatocellular carcinomas (Edmondson, 1958).

Although there is a higher incidence of benign hepatic tumours, specifically hepatic adenomas (Rooks et al., 1979) in oral contraceptive users, and although case reports have documented the occurrence of hepatocellular carcinoma in young women on oral contraceptives, a causal relationship has not been established (Helling \& Wood, 1982). Recently, two retrospective studies have demonstrated that there appears to be an increased relative risk for hepatocellular carcinoma in patients who have been taking the oral contraceptive, and that this relative risk increased with long-term use (Neuberger et al., 1986; Forman et al., 1986). The closely related steroids,

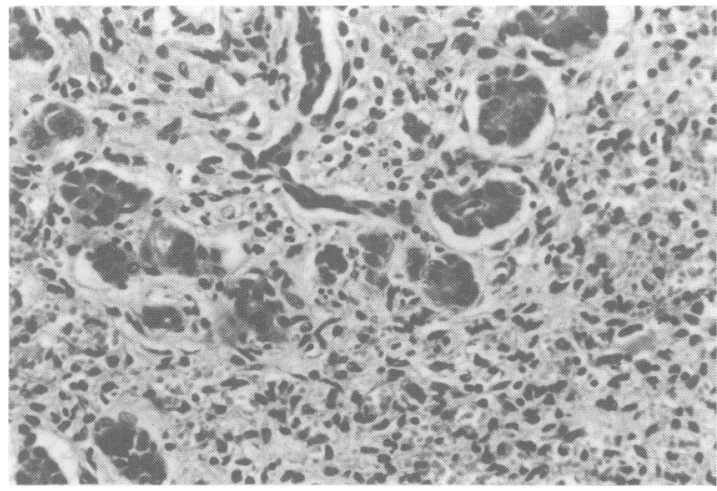

Figure 1 Acinar and trabecular liver cell carcinoma with conspicuous bile formation. Haematoxylin and eosin $\times 300$.

oxymethalone and methyl-testosterone, are known to induce malignant changes in men (Helling \& Wood, 1982). Our patient had stopped the oral contraceptive three years before presentation and although a subclinical, pre-malignant phase may have been induced at that time, this must be only speculation.

An interesting feature regarding our patient was the absence of $\alpha$-fetoprotein in her serum. $\alpha$-Fetoprotein is found in very high concentration in the serum of most $ᄋ$ but not all, patients with hepatocellular carcinoma (Purves, 1976). However, occasionally in patients neatô death, the serum concentration falls precipitously? (Kew, 1983), and this may explain why none was detected in our patient. Forman et al. (1986) noted that the tumours associated with oral contraceptive use usually occurred in non-cirrhotic livers and without associated hepatic fibrosis or raised $\alpha$-fetoprotein concentrations.

The marked elevation of serum ferritin observed in

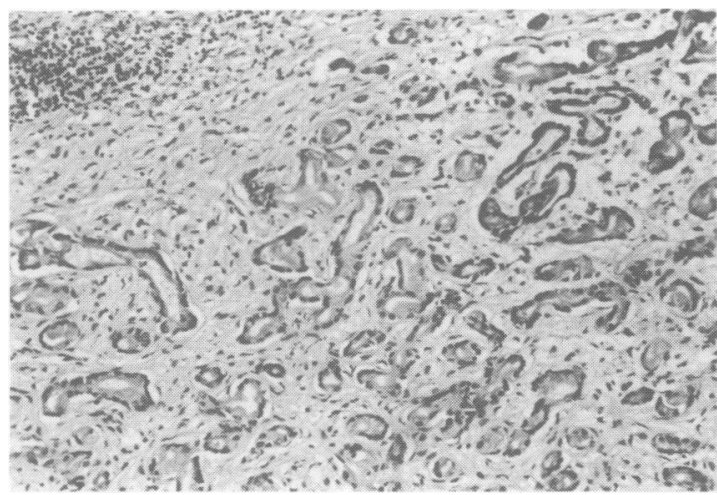

Figure 2 Edge of the intrahepatic nodule of the biliary type tumour. Haematoxylin and eosin $\times 125$. 
our patient is in keeping with the findings of Chapman et al. (1982) who found that serum ferritin was elevated in $63 \%$ of their patients with primary hepatocellular carcinoma. While it was not considered to be a useful screening test compared with $\alpha$ fetoprotein, they concluded that it may have a useful role in monitoring $\alpha$-fetoprotein-negative patients.

Although our patient had features indicative of cholestasis before admission, she presented to us with rapidly developing hepatic encephalopathy as a result of hepatic failure. There were no other features to suggest the diagnosis, which was not made until after death. Fulminant hepatic failure as a presenting feature of primary and secondary malignancies of the liver occurs rarely. It has been reported for nonhepatic malignancy in acute myeloblastic leukaemia (Hess \& Joyce, 1981), non-Hodgkin's lymphoma (Braude et al., 1982), pancreatic carcinoma (Mallory et al., 1946), oat cell carcinoma (Krauss et al., 1979) and small cell carcinoma (Harrison et al., 1981). In a review of hepatocellular carcinoma, Chlebowski et al.
(1984) reported three out of 121 patients presenting in an unresponsive state as a result of hepatic coma, but the clinical details are lacking. Stein et al. (1977) reported a multifocal malignant haemangioendothelioma of the liver, presenting as acute hepatitis. The fulminant hepatic failure in six cases of hepatocellular carcinoma reported by Okuda et al. (1976) was due to shock liver, following infarction of the non-cancerous liver parenchyma as a result of severe blood loss and systemic hypotension. Although the liver in our patient showed very extensive liver cell necrosis, a local vascular cause was not identified nor was a hypotensive episode apparent preceding the onset of hepatic failure. The cause of the necrosis and its role as the final factor precipitating the descent into hepatic failure is most likely to have been encroachment on and compression of hepatic lobules by massive expansion of a multifocal tumour. Therefore, to our knowledge, this is the only detailed case report of hepatocellular carcinoma presenting as fulminant hepatic failure.

\section{References}

BRAUDE, S., GIMSON, A.E.S., PORTMANN, B. \& WILlIAMS, R. (1982). Fulminant hepatic failure in non-Hodgkin's lymphoma. Postgraduate Medical Journal, 58, 301.

CHAPMAN, R.W., BASSENDINE, M.F., LAULICHT, M., GORMAN, A., THOMAS, H.C., SHERLOCK, S. \& HOFFBRAND, A.V. (1982). Serum ferritin and binding of serum ferritin to Concanavalin A as a tumour marker in patients with primary liver cell cancer and chronic liver disease. Digestive Diseases and Sciences, 27, 111.

CHLEBOWSKI, R.T., TONG, M., WEISSMAN, J., BLOCK, J.B., RAMMING, K.P., WEINER, J.M., BATEMAN, J.R. \& CHLEBOWSKI, J.S. (1984). Hepatocellular carcinoma diagnostic and prognostic features in North American patients. Cancer, 53, 2701.

EDMONDSON, H.A. (1958). Tumours of the liver and intrahepatic bile ducts. Atlas of Tumor Pathology, Section VII, F-25, p. 89. Armed Forces Institue of Pathology: Washington D.C.

FARHI, D.C., SHIKES, R.H., MURARI, P.J. \& SILVERBERG, S.G. (1983). Hepatocellular carcinoma in young people. Cancer, 52, 1516.

FORMAN, D., VINCENT, T.J. \& DOLL, R. (1986). Cancer of the liver and the use of oral contraceptives. British Medical Journal, 292, 1357.

HARRISON, H.B., MIDDLETON, H.M., CROSBY, J.H. \& DASHER JR., M.N. (1981). Fulminant hepatic failure: An unusual presentation of metastatic liver disease. Gastroenterology, 80, 820.

HELLING, T.S. \& WOOD, W.G. (1982). Oral contraceptives and cancer of the liver: a review with two additional cases. American Journal of Gastroenterology, 77, 504.

HESS, C.E. \& JOYCE, R.A. (1981). Acute myeloblastic leukaemia presenting as progressive hepatic failure. Southern Medical Journal, 74, 1028.

KEW, M.C. (1983). Hepatocellular carcinoma. Postgraduate
Medical Journal, 59, (Suppl. 4), 78.

KRAUSS, E.A., LUDWIG, P.W. \& SUMNER, H.W. (1979). Metastatic carcinoma presenting as fulminant hepatic failure. American Journal of Gastroenterology, 72, 651.

MALLORY, T.B., CASTLEMAN, B. \& PARRIS, E.E. (1946). Case records of the Massachusetts General Hospital: Weekly clinicopathological exercises. Case 32401. New England Journal of Medicine, 235, 521.

NEUBERGER, J., FORMAN, D., DOLL, R. \& WILLIAMS, R. (1986). Oral contraceptives and hepatocellular carcinoma. British Medical Journal, 292, 1355.

OKUDA, K., MUSHA, H., KANNO, H., IGARASHI, M., NAKANO, M., SHIMOKAWA, Y., KUBO, Y., ARISHIMA, T., HASHIMOTO, M., NAGATA, E., KOJIRO, M., SAKAMOTO, K. \& NAKASHIMA, T. (1976). Localised submassive liver cell necrosis as a terminal event of liver carcinoma. Cancer, 37, 1965.

PURVES, L.R. (1976). $\alpha$-Fetoprotein and the diagnosis of liver cell cancer. In Liver Cell Cancer, Cameron, H.M., Linsel, D.A. \& Warwick, G.P. (eds). p. 61. Elsevier: Amsterdam.

ROOKS, J.B., ORY, H.W., ISHAK, K.G., STRAUSS, L.T., GREENSPAN, J.R., HILL, A.P. \& TYLER, C.W. (1979). Epidemiology of hepatocellular adenoma: the role of oral contraceptive use. Journal of the American Medical Association, 242, 644.

SAUNDERS, S.J., SEGGIE, J., KIRSCH, R.E. \& TERBLANCHE, J. (1979). Acute liver failure. In Liver and Biliary DiseasePathophysiology, Diagnosis and Management, Wright, R., Alberti, K.G.M.M., Karran, S. \& Millward-Sadler, G.H. (eds). p. 569. Saunders Co.: London, Philadelphia \& Toronto.

STEIN, A.M., KAWAZ, K., TABRIZI, A., BLANCHARD, R. \& HOU, S. (1977). Multifocal malignant haemangioendothelioma presenting as acute hepatitis. American Journal of Gastroenterology, 67, 370. 